\title{
$O$ acesso à educação de adolescentes e jovens em conflito com a lei no âmbito do estado do Paraná
}

\section{Access to the education of adolescents and young people in conflict with the law in the context of the state of Parana}

\author{
Fabricio Veiga Costa ${ }^{1}$ \\ Ivan Dias da Motta ${ }^{2}$ \\ Fernando Nabão Lopes Ferreira ${ }^{3}$
}

\begin{abstract}
RESUMO: O presente trabalho tem como objetivo classificar a educação como um direito da personalidade, sob o enfoque de quea educação permite o pleno desenvolvimento do indivíduo. Busca-se, ainda, correlacionar a educação, o desenvolvimento e a personalidade, utilizando-se para tanto as teorias de Lev Semenovich Vygotsky. A educação básica é garantida no ordenamento jurídico pátrio por meio da elaboração de diversos sistemas e subsistemas, devendo ser assegurada a todos.Sob a égide do princípio da proteção Integral da criança e do adolescente, e as competências atribuídas pelos artigos $3^{\circ}, 4^{\circ}$ e $5^{\circ}$ da Lei 12.594/2012- SINASE, deve-se também garantir o direito à educação aos adolescentes e jovens que cumprem medidas socioeducativas.Considerando o crônico problema de efetivação de direitos no Brasil, somente após cinco anos da promulgação do SINASE, aregulamentação e a padronização do acesso à educação por meio da matrícula dos adolescentes e jovens em cumprimento de medidas socioeducativas foi efetivado no âmbito do Estado do Paraná. Por meio da pesquisa documental e bibliográfica, analisar-se-á a Instrução Normativa SUED/SEED n ${ }^{\circ}$ 10/2017 que regulamenta o procedimento de matrícula de adolescentes e jovens em cumprimento de medidas socioeducativas em meio aberto, em semiliberdade e em regime de internação no âmbito do Estado do Paraná. Tal Instrução Normativa visa efetivar o acesso à educação, bem como convergir com os objetivos das medidas, que são a reeducação e a ressocialização dos jovens em conflito com a lei.
\end{abstract}

Palavras-chave:Direitos da personalidade; Direito à educação; Medidas socioeducativas; Adolescentes em conflito com a lei; Estado do Paraná.

ABSTRACT: The present work aims to classify education as a right of the personality, under the focus that educational lows the full development of the individual. It is also sought to

\footnotetext{
${ }^{1}$ Doutorado em DIREITO PROCESSUAL pela PONTIFICIA UNIVERSIDADE CATOLICA DE MINAS GERAIS, professor e coordenador do Núcleo monografia da Faculdade Pedro Leopoldo - RS.

${ }^{2}$ Doutorado em Direito das Relações Sociais pela Pontifícia Universidade Católica de São Paulo, Associado Colaborador do Instituto Cesumar de Ciência, Tecnologia e Inovação.

${ }^{3}$ Mestrado em Ciências Jurídicas pelo Centro de Ensino Superior de Maringá.
} 
correlate education, development and personality, using the theories of Lev Semenovich Vygotsky. Basic education is guaranteed in the national legal order by mean soft he elaboration of several systems and subsystems, and must be guaranteed to all. Under the auspices of the principle of the integral protection of children and adolescents, and the powers conferred by Articles 3, 4 and 5 of Law 12,594 / 2012 - SINASE, it is also necessary to guarantee the right to education to adolescents and young people who comply with socioeducational measures. Considering the chronic problem ofen forcing rights in Brazil, only after five years of SINASE's promulgation, the regulation and standardization of access to education through the enrollment of adolescents and youths in compliance with socioeducationa measures was carried out within the scope of the State of Paraná .Through documentary and bibliographical research, Normative Instruction SUED / SEED n ${ }^{\circ}$ 10/2017 will be analyzed, which regulates the enrollment procedure of adolescents and youths in compliance with socio-educational measures in the open, semi-free and inpatient settings in the scope of the State of Paraná. This Normative Instruction aims at effective access to education, as well as converge with the objectives of the measures, which are there-education and resocialization of young people in conflict with thel aw.

Keywords: Personality rights; Right to education; Educational measures; Adolescents in conflict with the law; State of Parana.

\section{Introdução}

O presente artigo tem como objetivo o estudo da educação como um direito da personalidade e de sua importância para o pleno desenvolvimento da pessoa humana. Lev Semenovich Vygotsky entende que a educação é parte fundante do desenvolvimento, bem como da formação da personalidade de cada indivíduo, sendo então realizado correlações entre a educação, o desenvolvimento e a formação da personalidade do indivíduo.

Reconhecida a importância da educação, a Constituição Federal, sob aégide da máxima proteção da criança e do adolescente previsto no artigo 227, prevê também em seu artigo 205 a tutela da garantia do acesso à educação. Ocorre que esse acesso também deve ser garantido aos adolescentes e jovens que cumprem medidas socioeducativas, uma vez que ela dever ser universalizada. Dessa forma, cada ente federado deve implementar formas de acesso à educação básica àqueles que cumprem medidas em regime de internação, semiliberdade e em meio aberto.

Para tanto, sob o viés educacional, será realizada preliminarmente uma breve análise dos direitos educacionais, tratando-se especificamente das competências e atribuições da 
União, Estados e Municípios quanto à garantia da educação básica, inclusive àqueles em situações de restrição de liberdade, devendo cada ente federado efetivar a regulamentação,a formulação, instituição, coordenação e manutenção de seus respectivos sistemas de atendimento socioeducativo nos moldes dos seus artigos $3^{\circ}, 4^{\circ}$ e $5^{\circ}$ da Lei 12.594/2012.

Este "dever ser" tem esbarrado no problema crônico da não efetividade dosdireitos, especialmente quando se refere a educação, considerada um direito da personalidade e reflexo da interpretação sistemático-constitucionalizada do referido direito fundamental, expressamente previsto no plano constituinte. Dessa forma,argui-se como o SINASE e o direito à educação será, de fato,vocalizado em cada ente federativo quanto ao seu acesso.

Observa-se que, desde a promulgação da Lei 12.594 no ano de 2012, que institui o Sistema Nacional de Atendimento Socioeducativo - SINASE, somente em 24 de abril de 2017, ou seja, após transcorrido cinco anos, o Estado do Paranáefetivou e padronizou o acesso por meio da matrículacom a elaboração da Instrução Normativa $n^{\circ}$ 10/2017, emitida pela Secretaria de Estado da Educação e Superintendência da Educação - SUED/SEED.

Essa Instrução Normativa, que será objeto de análise, visa justamente atender e efetivar o previsto no SINASE, ou seja, a oferta, a qualificação e a consolidação do atendimento escolar de adolescentes e jovens em cumprimento de medidas socioeducativas em meio aberto, em regime de semiliberdade ou em internação.

A pergunta problema utilizada como parâmetro para a delimitação do objeto de pesquisa em questão é a seguinte: a Instrução Normativa nº 10/2017, emitida pela Secretaria de Educação do Estado do Paraná, é um meio de assegurar a efetividade do direito à educação e o pleno desenvolvimento da pessoa humana, quando regulamenta o acesso ao referido direito aos adolescentes em conflito com a lei?

Visando esclarecer cientificamente o objeto da pesquisa, inicialmente desenvolveu-se um estudo da educação como um direito da personalidade, demonstrando-se que seu objetivo é assegurar o pleno desenvolvimento da pessoa humana. Por meio da análise das competências e atribuições do sistema educacional, foi possível evidenciar a importância do referido direito, além da responsabilidade dos entes federativos quanto a sua efetivação.

$\mathrm{O}$ estudo da matrícula dos adolescentes e jovens em cumprimento de medidas socioeducativas no Estado do Paraná foi essencial para o debate especifico do objeto proposto, haja vista que o estudo detalhado dos respectivos jovens e adolescentes que 
cumprem medida de internação, semiliberdade ou medida em meio aberto foi de significativa importância para o estudo proposto.

Por meio da pesquisa bibliográfica e documental, tornou-se possível a realização do diálogo das fontes, a construção de análises interpretativas, comparativas e quantitativas dos dados levantados, essencial para responder a pergunta problema proposta. A utilização do método dedutivo foi de significativa importância para a delimitação do objeto da pesquisa, haja vista que se partiu de uma concepção macro analítica, qual seja, o estudo da educação como um direito da personalidade, objetivando-se analisar se tal direito é efetivamente assegurado aos jovens e adolescentes em conflito com a lei no Estado do Paraná.

\section{2. $\mathrm{O}$ direito à educação como direito da personalidade}

Regina Muniz (2002, p. 52), explica que o direito da personalidade, como direito subjetivo, ganhou destaque na evolução do direito alemão, após a Segunda Guerra Mundial, que o reconheceu como "Direito Geral da Personalidade". A Lei Fundamental da República Federal de 23 de maio de 1949 proclamou que a dignidade do homem é inviolável, que todo o poder público é obrigado a respeitá-la e a protegê-la. Ela reconhece também o direito de cada um ao "livre desenvolvimento de sua personalidade desde que não acarrete violação aos direitos de outrem, à ordem constitucional ou à lei moral" (artigo $2^{\circ}$, parágrafo $1^{\circ}$ ) (MUNIZ, 2002, p. 52). Em aresto de 25 de maio de 1954 foi consagrada a existência nas relações privadas de um direito geral da personalidade, definido como "o direito de um particular contra outro particular ao respeito de sua dignidade de homem e ao desenvolvimento de sua personalidade individual" (MUNIZ, 2002, p. 52).

A Constituição Federal, que não pretende ser uma ordenação axiologicamente neutra, funda no título dos Direitos Fundamentais uma ordem objetiva de valores, por meio da qual se expressa um fortalecimento da validade dos direitos fundamentais. Esse sistema de valores, que tem seu ponto central no livre desenvolvimento da personalidade e na dignidade humana no seio da comunidade social deve valer como decisão fundamental para todos os ramos do direito; legislação, administração e jurisprudência recebem dele diretrizes e impulsos (SILVA, 2011, p. 140).

Para Carlos Alberto Bittar (1999, p. 1-7), os direitos reconhecidos à pessoa humana tomada em si mesma e em suas projeções na sociedade são considerados como da 
personalidade, previsto no ordenamento jurídico exatamente para a defesa de valores inatos no homem, como a vida, a higidez física, a intimidade, a honra, a intelectualidade e outros tantos.Bittar entende que os direitos da personalidade constituem direitos inatos - como a maioria dos escritores ora atesta, cabendo ao Estado apenas reconhece-los e sancioná-los em um ou outro plano de direito positivo - seja ele constitucional ou em legislação ordinária -, e dotando-os de proteção própria, conforme o tipo de relacionamento a que se volte, a saber: contra o arbítrio do poder público ou as incursões de particulares.Ainda, classifica os direitos da personalidade da seguinte forma:
a) Direitos físicos; b) direitos psíquicos; c) direitos morais; os primeiros referentes a componentes materiais da estrutura humana (a integridade corporal, compreendendo: o corpo, como um todo; os órgãos; os membros; a imagem, ou efigie); os segundos, relativos a elementos intrínsecos à personalidade (integridade psíquica, compreendendo: a liberdade; a intimidade; o sigilo) e os últimos, respeitantes a atributos valorativos (ou virtude) da pessoa na sociedade (o patrimônio moral, compreendendo: a identidade; a honra; as manifestações do intelecto) (BITTAR, 1999, p. 17).

Os referidos direitos têm função especial em relação à personalidade, constituindo o minimum necessário e imprescindível ao seu conteúdo. Considera-se, no entanto, que devem ser incluídos como direitos da personalidade apenas os reconhecidos pelo Estado, que lhes dá força jurídica. Não se aceita, pois, a existência de meros direitos inatos, que constituíram exigências de ordem moral, quando situado o observador no plano do direito positivo. Em conclusão, acentua-se que todos os direitos subjetivos derivam do ordenamento positivo: daí sua delimitação no direito positivo em cada caso (BITTAR, 1999, p. 6-7).

Fernanda Cantali (2009, p. 61)entende que a repersonalização do direito é decorrente da preocupação com a valorização do ser humano, protegendo-se sua dignidade existencial, dignidade essa que, elevada a fundamento da República, colocou o indivíduo como o centro do ordenamento, como principal destinatário da ordem jurídica. A magnitude da tutela dos direitos da personalidade representa aquilo que é intrínseco à condição humana, devendo encontrar abrigo, primeiramente, na Constituição, já que são direitos indissociáveis da categoria dos direitos do homem.

Com a eleição da dignidade da pessoa humana como valor fundante de toda a ordem jurídica, o ser humano passou a ser o centro referencial do ordenamento, e os direitos ligados à sua personalidade tomaram posição de destaque. A pessoa não é mais tida apenas "como sujeito de direitos, categoria abstrata, elemento da relação jurídica”, mas passa a ser 
considerada "como bem jurídico tutelável: não como objeto de direito, mas como valor expresso na tutela das situações subjetivas existenciais". A pessoa vale pelo que é, e não apenas pelo que tem (CANTALI, 2009, p. 204).

A personalidade se resume ao conjunto de caracteres do próprio indivíduo, consiste na parte intrínseca da pessoa humana. Trata-se de um bem, no sentido jurídico, sendo o primeiro bem pertencente à pessoa, é a sua primeira utilidade. Através da personalidade, a pessoa poderá adquirir e defender os seus demais bens, jurídicos ou não. Tradicionalmente, os bens dos homens vêm sendo protegidos tanto pelos efeitos reflexos do direito objetivo como pelo direito subjetivo, sendo suas naturezas diversas (SZANIAWSKI, 2005, p. 70).

Essenciais ao desenvolvimento da personalidade humana individual são também os direitos à informação, à educação, à cultura, e à ciência, bem como à autodeterminação informacional, educativa, cultural e científica. Com efeito, o conhecimento e a autoavaliação do estado das causas e dos efeitos das ideias e dos fenômenos naturais, político-econômicos e socioculturais são absolutamente necessários à compreensão do homem e do mundo que o rodeia, à formação da opinião, do sentido crítico e da vontade individuais e à consequente organização, livre e adequada da atividade individual (SOUZA, 2011, p. 354).

Na contemporaneidade, a educação passou a ser entendida como um processo que visa o pleno desenvolvimento da pessoa, seu preparo para o exercício da cidadania e sua qualificação para o trabalho, sendo fator indispensável à evolução integral e harmônica do ser humano. A educação é a manifestação cultural que, de maneira sistemática e intencional, forma e desenvolve o homem em todos os aspectos que compõe sua personalidade (LAGO, 2013, p. 32).Para Capelo de Souza (2011, p. 353-354):

Tal bem jurídico impõe a possibilidade de emergência das forças energéticas e transformadora, interiores, de cada homem; a garantia de meios e condições existenciais e convivências, tanto naturais como sociais, suficientes para todo o homem se poder desenvolver e a salvaguardar do poder de autodeterminação de cada homem e de auto constituição da sua personalidade individual. Daqui resultam quer poderes jurídicos, para o respectivo titular, de afirmar e de promover o desenvolvimento da sua concreta personalidade (não apenas face aos demais homens e às pessoas coletivas privadas, nas relações jurídicas privadas, mas também face ao Estado e aos outros entes públicos, máxime, à participação político-social e às prestações públicas no domínio, $v$. $g$., da saúde, da informação, do ensino, da segurança social, da Educação, da formação profissional, da habitação e da cultura, bem como no que diz respeito às relações jurídicas privadas em que tais entidades públicas ajam despidas do seu ius imperii) quer deveres jurídicos de abstenção, para os demais homens e pessoas coletivas 
privadas ou públicas, de impedir, de dificultar, de perturbar, ou por qualquer modo, de prejudicar tal desenvolvimento da personalidade, relativamente não só a direitos ou interesses jurídicos privados mas também a direitos e interesses subjetivos públicos do titular dos direitos ao desenvolvimento da personalidade própria. (grifos nossos)

O desenvolvimento pleno do ser humano depende do aprendizado que realiza num determinado grupo cultural, a partir da interação com outros indivíduos da sua espécie. A criança só aprenderá a falar se pertencer a uma comunidade de falantes, ou seja, as condições orgânicas (possuir o aparelho fonador), embora necessárias, não são suficientes para que o indivíduo adquira a linguagem. Nessa perspectiva, é o aprendizado que possibilita e movimenta o processo de desenvolvimento, ou seja, o aprendizado pressupõe uma natureza social específica e um processo através do qual as crianças penetram na vida intelectual daqueles que as cercam. Desse ponto de vista, o aprendizado é o aspecto necessário e universal, uma espécie de garantia do desenvolvimento das características psicológicas especificamente humanas e culturalmente organizadas (REGO, 1984, p. 89-103).

O desenvolvimento psicointelectual da criança realiza-se no processo de interação com o ambiente natural e social. Conduzir o desenvolvimento através da educação significa organizar esta interação, dirigir a atividade da criança para o conhecimento da realidade e para o domínio, por meio da palavra, do saber e da cultura da humanidade, desenvolver concepções sociais, convicções e normas de comportamento moral. O problema mais importante a esse respeito é o da relação recíproca entre aprendizagem, educação e desenvolvimento (KOSTIUK, 2005, p. 44).

Lev Semenovich Vygotsky (2005, p. 25)expõe três teorias referentes à relação entre a aprendizagem e o desenvolvimento. Ensina que, o desenvolvimento deve atingir uma determinada etapa, com a consequente maturação de determinadas funções, antes da escola fazer adquirir à criança determinados conhecimentos e hábitos. $\mathrm{O}$ curso do desenvolvimento precede sempre o da aprendizagem. A aprendizagem segue sempre o desenvolvimento.O aprendizado é considerado um processo puramente externo que não está envolvido ativamente no desenvolvimento. Ele simplesmente se utilizaria dos avanços do desenvolvimento ao invés de fornecer um impulso para modificar seu curso (VYGOTSKY 1998, p. 104).

Outra proposta para a relação entre aprendizagem e desenvolvimento estudada por Vygotsky (2005, p. 27-28) é que a aprendizagem significa desenvolvimento. A educação pode ser definida como a organização de hábitos de comportamento e de inclinações para a ação. $\mathrm{O}$ 
desenvolvimento e a aprendizagem sobrepõem-se constantemente. $O$ seu principio fundamental é a simultaneidade, a sincronização entre os dois processos. Nesse sentido, o desenvolvimento é visto como o domínio dos reflexos condicionados, não importando se o que se considera é o ler, o escrever ou a aritmética. Ou seja, o processo de aprendizado está completa e inseparavelmente misturado com o processo de desenvolvimento (VYGOTSKY 1998, p. 105).

A terceira teoria tenta conciliar os dois primeiros. O processo de desenvolvimento está concebido como processo independente ao de aprendizagem, mas por outro lado a mesma aprendizagem, no decurso do qual a criança adquire toda uma nova série de formas de comportamentos, considera-se coincidente com o desenvolvimento, ou seja, há uma interação de dois processos fundamentais (VYGOTSKY 2005, p. 28).

$\mathrm{O}$ ensino nas escolas não pode se limitar apenas a transmitir ao discípulo determinados conhecimentos, a formar um mínimo de aptidões e de hábitos. A sua tarefa é desenvolver o pensamento dos alunos, a sua capacidade de analisar e generalizar os fenômenos da realidade, de raciocinar corretamente, resumindo, desenvolver "no todo" as suas faculdades mentais. Se o intento é de alcançar essa meta, tem de se encontrar uma solução satisfatória para os problemas mais urgentes do ensino. O desenvolvimento do pensamento lógico é um dos fatores mais importantes do sucesso escolar (KOSTIUK, 2005, p. 49-50).

Dessa forma, o direito à educação não é somente um direito social fundamental, mas é considerado modernamente, também, como um "direito da personalidade", no sentido de que o conhecimento é uma necessidade básica do ser humano. $\mathrm{O}$ direito à vida, por exemplo, é um direito indisponível e inerente ao ser humano. Portanto, como direito personalíssimo, deve ser visto na ótica dos direitos humanos ou naturais.O direito da personalidade vincula-se ao direito à educação como valores fundamentais, que se revelaram no processo histórico, mais precisamente nesse terceiro milênio, como proteção da vida e da dignidade humana (JOAQUIM, 2009, p. 196).

A educação é condição sine qua non para que o indivíduo possa desenvolver plenamente suas inúmeras capacidades e formar sua personalidade. Daí dizer que é a educação é um direito fundamental na qual se assenta todo o desenvolvimento do ser humano (MOTTA; FREITAS, 2015, p. 48).Toda a educação determina o desenvolvimento da personalidade da criança e do adolescente, deixando nela um vestígio. Todavia, é necessário 
observar em que condições a educação satisfaz realmente esses objetivos e contribuir por esse meio, praticamente, para a previsão dos fenômenos negativos no desenvolvimento dessas qualidades (morais e outras) da personalidade do adolescente, que interessam diretamente à sociedade (KOSTIUK, 2005, p. 54).

Para a garantia do direito à educação, se faz necessária a sistematização desse direito, ou seja, a elaboração de leis, princípios, atos normativos, normas programáticas, resoluções, entre outros, bem como a vocalização desses direitos através da implementação de política públicas de promoção humana para a efetivação desses direitos. A demonstração da importância da regulamentação do direito à educação no plano infraconstitucional é fundamental para o debate crítico do objeto da presente pesquisa, especialmente no que atine ao exercício do referido direito pelos jovens em conflito com a lei no Estado do Paraná, conforme a seguir debatido.

\section{Competências e atribuições do sistema educacional brasileiro}

Renato Alberto Teodoro Di Dio (apud JOAQUIM, 2009, p. 25) ensina que o direito educacional é o conjunto de normas, princípios, leis e regulamentos que versam sobre as relações de alunos, professores, administradores, especialistas e técnicos, enquanto envolvidos, mediata ou imediatamente, no processo ensino-aprendizagem. Nelson Joaquim (2009, p. 115-116), por sua vez, conceitua como um conjunto de normas, princípios, institutos jus pedagógicos, procedimentos e regulamentos, que orientam e disciplinam as relações entre alunos e/ou responsáveis, professores, administradores educacionais, diretores de escolas, gestores educacionais, estabelecimentos de ensino e o poder público, enquanto envolvidos diretamente ou indiretamente no processo de ensino-aprendizagem, bem como investiga as interfaces com outros ramos da ciência jurídica e do estabelecimento.

O direito educacional estuda as origens e os fundamentos legais do processo educativo, a sua estrutura legislativa e os seus propósitos pedagógicos, assim como os fundamentos sociais e políticos dos currículos, programas e métodos de ensino e avaliação (BASTOS, 2000, p. 9).No campo da educação, um sistema agregará tanto o conjunto de instituições educacionais (compreendidos os elementos materiais e humanos que as compõem), como as normas nacionais editadas pela União e as normas especiais que o 
vinculam a tal ou qual ente federado (RANIERI, 2000, p. 118).Dermeval Saviani (2012, p. 26-27) explica que:

[...] considera a Educação sistemática como uma pluralidade de setores unificado entre si harmonicamente: um conjunto de partes organicamente relacionadas entre si. [...] Do ponto de vista institucional: uma instituição ou conjunto de instituições em que se realiza a Educação. A partir do fenômeno, o sistema, qualquer que ele seja, está sempre referido à realidade humana, o seu uso denota uma realidade não apenas constatada pelo homem, mas criada, organizada por ele. O sistema é um produto humano [...] há a intencionalidade $[\ldots]$.

Na educação, sistema não é a mera justaposição ou soma das escolas que constituem as redes de ensino, mas um novo sujeito, interescolar, interredes, interinstâncias, governamentais ou não, que respeita a individualidade das unidades menores e as articula em um todo mais vasto, em ator transindividual, com uma nova performance educacional (ROMÃO, 2010, p. 80).O Sistema Educacional Brasileiro ou Sistema Nacional de Educação está assentado em um processo de estruturação que combina continuidade e terminalidade. Se, por um lado, é constituído por partes relativamente independentes, combinado elementos diversos (componentes curriculares, metodologias e procedimentos didático-pedagógicos) com uma relativa articulação horizontal, conferindo graus (terminalidade) a seus concluintes. Por outro, as partes constitutivas são subsequentes e complementares, no sentido de que cada grau é preparatório (continuidade) para o próximo, apresentando um relativo grau de articulação vertical (ROMÃO, 2010, p. 80). Nessa perspectiva teórica, José Afonso da Silva (1999, p. 481) resume as competências:

[...] quanto à participação de uma ou mais entidades na esfera da normatividade ou da realização material, [...] a competência se distingue em: (a) exclusiva, quando é atribuída a uma entidade com exclusão das demais (artigo 21); (b) privativa, quando enumerada como própria de uma entidade, com possibilidade, no entanto, de delegação e de competência suplementar (artigo 22 e parágrafo único, e artigo 24 e seus parágrafos); a diferença entre a exclusiva e privativa está nisso, aquela não admite suplementariedade nem delegação; (c) comum, cumulativa ou paralela, reputadas expressões sinônimas, que significa a faculdade de legislar ou pratica certos atos, em determinada esfera, juntamente e em pé de igualdade, consistindo, pois, num campo de atuação comum às várias entidades, sem que o exercício de uma venha a excluir a competência de outra, que pode assim ser exercida cumulativamente (artigo 23); (d) concorrente, cujo conceito compreende dois elementos: possibilidade de disposição sobre o mesmo assunto ou matéria por mais de um entidade federativa; primazia da União no que tange à fixação de normas gerais (artigo 24 e seus parágrafos); (e) suplementar, 
que é correlativa da competência concorrente, e significa o poder de formular normas que desdobrem o conteúdo de princípios ou normas gerais ou que supram a ausência ou omissão destas (artigos $24, \S \S 1^{\circ}$ a $4^{\circ}$ ).

No âmbito educacional brasileiro, a repartição de competências materiais demonstra atribuições concorrentes e descentralizadoras, objetivando uma cooperação recíproca entre os entes federados, cada qual em sua área específica de execução, principalmente no oferecimento da Educação básica. Existe uma compatibilização entre competências privativas e comuns para nortear as políticas públicas educacionais. Assim, a União aparece, em nível hierarquicamente superior, na edição de normas gerais educacionais, em todos os níveis, tendo atuação coordenadora, supletiva e redistributiva em todo o sistema nacional. No ensino superior, o Governo Federal atua com prevalência relativa nos níveis de competência, obrigações e gestão de todo o sistema (GOMES, 2011, p. 170).

No caso brasileiro, o princípio geral que norteia a repartição de competências entre as entidades componentes do Estado federal é o da predominância dos interesses. Segundo tal principio à União, cabem àquelas matérias e questões de predominante interesse geral e nacional, ao passo que aos Estados tocam matérias e assuntos de predominante interesse regional, e aos Municípios concernem os assuntos de interesse local (SOUSA, 2010, p. 42).

$\mathrm{Na}$ repartição vertical de competências, realiza-se a distribuição da mesma matéria entre a União e os Estados-membros. Essa técnica, no que tange às competências legislativas, deixa para a União os temas gerais, os princípios de certos institutos, permitindo aos Estadosmembros afeiçoar a legislação às suas peculiaridades locais. A técnica da legislação concorrente estabelece um verdadeiro condomínio entre União e Estados-membros (SOUSA, 2010, p. 44).

A repartição horizontal ocorre pela atribuição a cada ente federativo, de uma área reservada que lhe cabe disciplinar em toda a sua extensão. Dessa forma, a repartição vertical distribui uma mesma matéria por diferentes níveis, do geral ao particular, entre os entes federativos. Competências privativas e comuns decorrem da repartição horizontal e as competências concorrentes, da repartição vertical (RANIERI, 2000, p. 93).

A técnica cumulativa permite que os entes federados avancem na disciplina das matérias, desde que o ente superior não o faça, independente de limites prévios. Já a técnica de não acumulação reserva ao ente central uma parcela de competências para uniformizar determinada matéria, ao mesmo tempo em que atribui aos demais entes federados um campo 
de competência suplementar, para conformar as diretrizes, bases ou fundamentos daquela uniformização às peculiaridades (RANIERI, 2000, p. 95).

Saviani (2012, p. 75-76) leciona, ainda, que a educação sistematizada, para ser tal, deverá preencher os requisitos apontados em relação à atividade sistematizadora em geral. Segundo o Aator, o homem é capaz de educar de modo sistematizado quando toma consciência da situação (estrutura) educacional, capta os seus problemas, reflete sobre eles, formula-os em termos de objetivos realizáveis, organiza meios para alcançar os objetivos, instaura um processo concreto que os realiza e mantém ininterrupto o movimento dialético ação-reflexo-ação (SAVIANI, 2012, p. 75-76).

A constituição brasileira de 1988 deixa claro ainda que a educação básica, como gênero, englobará a educação infantil, o ensino fundamental e o ensino médio, conforme, aliás, já se extraía da Lei de Diretrizes e Bases da Educação Nacional e do Plano Nacional de Educação (ROSSATO; LÉPORE; CUNHA, 2012, p. 245).

Na composição da educação básica, a educação infantil é prestada às crianças de zero a cinco anos de idade. No ensino fundamental, que se inicia aos seis anos e terá duração de noves anos, é assegurada a todos os que não tiveram acesso na idade própria. Já no ensino médio, terá duração de três anos, assegurada, também, a sua oferta a todos os que não tiveram acesso na idade própria. Em todos os casos, a oferta será sempre obrigatória e gratuita.

O papel do Estado na ação educativa inicia-se com sua obrigação de construir, organizar e manter escolas, proporcionando a democratização e a gratuidade do ensino, especialmente no nível constitucional de obrigatoriedade, bem como zelar pelo respeito às leis do ensino, pela avaliação das instituições e pelo desenvolvimento do nível de qualidade do ensino (MOTTA, 1997, p. 168).

José Afonso da Silva (1999, p. 810) leciona, ao comentar sobre os princípios básicos do ensino, que a consecução prática dos objetivos da Educação consoante do artigo 205, ou seja, "pleno desenvolvimento da pessoa, seu preparo para o exercício da cidadania e sua qualificação para o trabalho", só se realizará num sistema educacional democrático, em que a organização da Educação formal (via escola) concretize o direito ao ensino, informados por princípios com eles coerentes, que, realmente, foram acolhidos pela Constituição. 
O artigo 227 da Constituição combinado com o artigo $4^{\circ}$ do Estatuto da Criança e do Adolescente $^{4}$ é reconhecido na comunidade internacional como a síntese da Convenção das Organizações das Nações Unidas de 1989, ao declarar os direitos especiais da criança e do adolescente. A determinação da prioridade absoluta para o infanto-adolescente como norma constitucional há de entender-se por primazia ou preferência para as políticas sociais públicas, como dever da família, da comunidade, da sociedade civil e do poder público (JOAQUIM, 2009, p. 152). À Constituição Federal de 1988 incumbe competências matérias aos entes federados. No artigo 211, parágrafos $1^{\circ}, 2^{\circ}, 3^{\circ 5}$ do texto constitucional são realizadas a discriminação dessas competências por esfera de governo ${ }^{6}$.

A sistemática de distribuição e a organização dos sistemas de ensino no Brasil são decorrentes do princípio federativo, que é norteador da Constituição e determinante da forma do Estado brasileiro. Assim, no Estado federativo brasileiro, os diversos entes (União, Estados-membros e Municípios) devem desenvolver suas atividades com o intuito específico de cooperação mútua, de atingir os objetivos da República, os quais constituem princípios gerais norteadores do ordenamento jurídico brasileiro (SOUSA, 2010, p.44-45).

O princípio da máxima efetividade, também chamado de princípio da eficiência interpretativa ou da interpretação efetiva, tem como objetivo imprimir eficácia social ou efetividade às normas constitucionais, extraindo-lhes o maior conteúdo possível, principalmente em matéria de Direitos Humanos Fundamentais. A palavra de ordem é

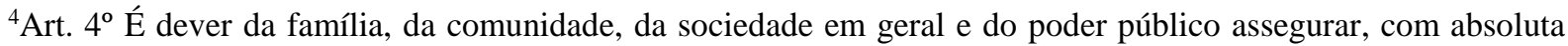
prioridade, a efetivação dos direitos referentes à vida, à saúde, à alimentação, à Educação, ao esporte, ao lazer, à profissionalização, à cultura, à dignidade, ao respeito, à liberdade e à convivência familiar e comunitária. Parágrafo único. A garantia de prioridade compreende: a) primazia de receber proteção e socorro em quaisquer circunstâncias; b) precedência de atendimento nos serviços públicos ou de relevância pública; c) preferência na formulação e na execução das políticas sociais públicas; d) destinação privilegiada de recursos públicos nas áreas relacionadas com a proteção à infância e à juventude. BRASIL. Estatuto da Criança e do Adolescente - Lei 8069/90. Disponível em: http://www.planalto.gov.br/ccivil_03/leis/L8069.htm. Acesso em: 19 ago. 2018.

${ }^{5}$ BRASIL. Constituição da República Federativa do Brasil de 1988. Disponível em: http://www.planalto.gov.br/ccivil_03/constituicao/constituicaocompilado.htm. Acesso em: 30 maio 2018.

6“Art. 211. A União, os Estados, o Distrito Federal e os Municípios organizarão em regime de colaboração seus sistemas de ensino.§ $1^{\circ}$ A União organizará o sistema federal de ensino e o dos Territórios, financiará as instituições de ensino públicas federais e exercerá, em matéria educacional, função redistributiva e supletiva, de forma a garantir equalização de oportunidades educacionais e padrão mínimo de qualidade do ensino mediante assistência técnica e financeira aos Estados, ao Distrito Federal e aos Municípios; $§ 2^{\circ}$ Os Municípios atuarão prioritariamente no ensino fundamental e na Educação infantil. $\S 3^{\circ}$ Os Estados e o Distrito Federal atuarão prioritariamente no ensino fundamental e médio". BRASIL. Constituição da República Federativa do Brasil de 1988. Disponível em: http://www.planalto.gov.br/ccivil_03/constituicao/constituicaocompilado.htm. Acesso em: 30 maio 2018.
} 
conferir às normas uma interpretação que as leve a uma realização prática, fazendo prevalecerem os fatos e os valores nelas consignados (BULOS, 2014, p. 461).

Normas limitadas por princípio programático são as que estatuem programas a serem desenvolvidos pelo Estado. Em vez de regular, desde o dia em que nascem, certos assuntos, apenas transferem para o legislador tal encargo, estipulando o que ele poderá, ou não, fazer. Também conhecidas como normas programáticas, diretórias ou diretivas, cingem-se a enunciar as linhas diretoras que devem ser perseguidas pelos poderes públicos, como saúde, educação, lazer, moradia. Elas comandam o seu próprio procedimento legislativo, consagrando programas constitucionais a serem cumpridos mediante legislação integrativa da manifestação constituinte. As normas programáticas não contemplam interesses ou direitos regulados em si, mas, apenas, metas ou escopos a serem seguidos pelo legislativo, executivo e judiciário. Buscam a consecução dos fins sociais pelo Estado, motivo por que desempenham junção eficacial de programa (BULOS, 2014, p. 484).

Dessa forma, a Constituição da República Federativa do Brasil de 1988, o Estatuto de Criança e do Adolescente (Lei n. 8.069/1990) e a Lei de Diretrizes e Bases da Educação (Lei n. 9.394/1996) dispõem expressamente sob o princípio da igualdade de condições, de acesso e permanência na escola. Há disposições expressas que determinam a estrita observância deste direito por injunção legal, conforme redação dos artigos 206, 53 e 3, respectivamente.

Ao enumerar direitos, estabelecer princípios e diretrizes da política de atendimento, definir competências e atribuições gerais, e dispor sobre os procedimentos judiciais que envolvem crianças e adolescentes, a Constituição Federal e o Estatuto da Criança e do Adolescente instalaram um sistema de "Proteção Geral de Direitos" de crianças e adolescentes, cujo intuito é a efetiva implementação da Doutrina da Proteção Integral, denominado Sistema de Garantia de Direitos (SGD). Nele, também se incluem princípios e normas que regem a política de atenção a crianças e adolescentes, cujas ações são promovidas pelo poder público em suas 03 esferas (União, Estados, Distrito Federal e Municípios), pelos 03 poderes (Executivo, Legislativo e Judiciário) e pela sociedade civil, sob três eixos: Promoção, Defesa e Controle Social. A opção pela forma de sistema tem como finalidade melhor ordenar as várias questões que gravitam em torno da temática, reduzindo-se, assim, a complexidade inerente ao atendimento aos direitos desse público (BRASIL, Sistema Nacional de Atendimento Socioeducativo). 
No interior do sistema de garantia de direitos (SGD) existem diversos subsistemas que tratam, de forma especial, de situações peculiares. Dentre outros subsistemas, incluem-se àqueles que regem as políticas sociais básicas, de assistência social, de proteção especial e de justiça voltados ao atendimento de crianças e adolescentes. É, nesse contexto, que se insere o atendimento ao adolescente em conflito com a lei, desde o processo de apuração, aplicação e execução de medida socioeducativa. Pode-se dizer que a reunião de suas regras e critérios, de forma ordenada e que almeje reduzir as complexidades de atuação dos atores sociais envolvidos, possibilita a construção de um subsistema que, inserindo-se no SGD, atua sobre esse ambiente específico relacionado a esses adolescentes. A esse subsistema específico dá-se o nome de Sistema Nacional de Atendimento Socioeducativo (SINASE), o qual se comunica e sofre interferência dos demais subsistemas internos ao Sistema de Garantia de Direitos (tais como Saúde, Educação, Assistência Social, Justiça e Segurança Pública) (BRASIL, Sistema Nacional de Atendimento Socioeducativo).

O SINASE foi aprovado na assembleia do CONANDA $^{7}$ em 13 de julho de 2006 e representou um grande avanço em termos de políticas públicas voltadas para os adolescentes autores de ato infracional. Em 13 de julho de 2007, o SINASE foi apresentado por meio do Projeto de Lei $\mathrm{n}^{\circ}$ 1.627/2007 ao Plenário da Câmara dos Deputados. Em 9 de novembro do mesmo ano, por Ato da Presidência da Câmara foi criada uma Comissão Especial para analisar o projeto de lei (VERONESE, 2009, p. 37).

O Conselho Nacional dos Direitos da Criança e do Adolescente - CONANDA tem sua atividade voltada a baixar normas complementares ao SINASE, avaliar o andamento das unidades ${ }^{8} \mathrm{em}$ todo o Brasil e os planos de atendimento desenvolvidos, bem como fiscalizá-lo (NUCCI, 2015, p. 821-822).

O Sistema Nacional de Atendimento Socioeducativo - SINASE representa um sistema, voltado à execução de medidas socioeducativas. Esta lei propõe regras gerais para esse cenário, que devem ser adotadas por todas as Varas da Infância e Juventude, em busca da padronização de métodos para executar as medidas aplicadas aos adolescentes infratores. Tem

${ }^{7} \mathrm{O}$ CONANDA foi criado por Lei Federal n. ${ }^{\circ}$ 8.242, de 12 de outubro de 1991. Disponível em: http://www.planalto.gov.br/ccivil_03/leis/L8242.htm. Acesso em: 29 dez. 2017.

${ }^{8}$ A "Unidade" designada ao cumprimento de medidas legais judicialmente destinada a adolescentes encontra-se legalmente conceituada como a base física necessária para a organização e o funcionamento de programade atendimento (parágrafo $4^{\circ}$ do artigo $1^{\circ}$ do SINASE). No estado do Paraná, as unidades recebem a denominação de Centros de SocioEducação - CENSE. BRASIL.Lei nº 12.594, de 18 de janeiro de 2012. Sistema Nacional de Atendimento Socioeducativo - SINASE. Disponível em: http://www.planalto.gov.br/ccivil_03/_ato20112014/2012/lei/112594.htm. Acesso em: 09 maio 2018. 
o seu aspecto positivo, pois, o Estatuto da Criança e do Adolescente falhou nesse importante ponto, deixando uma lacuna, suprida pela doutrina e pela aplicação prática de juízes (NUCCI, 2015, p. 818).

Trata-se de uma política pública destinada à inclusão do adolescente em conflito com a lei, que se correlaciona e demanda iniciativas dos diferentes campos das políticas públicas e sociais. O SINASE é um conjunto ordenado de princípios, regras e critérios, de caráter jurídico, político, pedagógico, financeiro e administrativo, que envolve desde o processo de apuração de ato infracional até a execução de medidas socioeducativas. (artigos 2 e 3 da Resolução no 119, de 11 de dezembro de 2006) ${ }^{9}$.

As atribuições legais (competências) exclusivamente determinadas à União contemplam a obrigatoriedade de formular e coordenar a efetivação da política pública nacional de atendimento socioeducativo (RAMIDOFF, 2012, p.19).A elaboração do Plano Nacional de Atendimento Socioeducativo, por sua vez, torna efetiva a integração da União com os Estados, o Distrito Federal e os Municípios. (inciso II do artigo $3^{\circ}$ do SINASE).Dessa forma, são comuns à União, aos Estados, ao Distrito Federal e aos Municípios, no âmbito de atuação de cada uma destas esferas de governo (BRASIL, Sistema Nacional de Atendimento Socioeducativo):

1)estabelecer normas sobre o atendimento socioeducativo mediante a edição de leis, decretos, resoluções (expedidas pelos Conselhos dos Direitos e Setoriais), portarias, instruções normativas e demais atos normativos e administrativos;

2) financiar, conjuntamente com os entes federativos, a execução de programas e ações destinados ao atendimento inicial de adolescente em processo de apuração de ato infracional ou que esteja sob medida socioeducativa;

3) garantir a publicidade de todas as informações pertinentes à execução das medidas socioeducativas;

4) garantir transparência dos atos públicos pertinentes à execução das medidas socioeducativas;

5) fornecer, via Poder Executivo, os meios e os instrumentos necessários ao pleno funcionamento dos respectivos Conselhos dos Direitos da Criança e do Adolescente, respeitando os princípios da paridade e do caráter deliberativo e controlador que regem tais órgãos;

${ }^{9}$ BRASIL. Conselho Nacional dos Direitos das Crianças e dos Adolescentes - CONANDA. Resolução n. ${ }^{\circ} 119$, de 11 de Dezembro de 2006. CONSELHO NACIONAL DOS DIREITOS DA CRIANÇA E DO ADOLESCENTE - CONANDA.Disponível em: http://www.crianca.mppr.mp.br/arquivos/File/download/resolucao_119_conanda_sinase.pdf. Acesso em 05 dez. 2017. 
6) elaborar e aprovar junto ao competente Conselho dos Direitos da Criança e do Adolescente o Plano de Atendimento Socioeducativo;

7) atuar na promoção de políticas que estejam em sintonia com os princípios dos direitos humanos e contra o racismo, a discriminação racial, a xenofobia e intolerância correlatas;

8) implementar programas em parceria com a sociedade civil organizada, ONG's e instituições afins com o propósito de garantir os direitos das populações e grupos discriminados, desfavorecidos ou em situação de vulnerabilidade social. (grifos nossos)

A União deverá prestar assistência técnica e de suplementação financeira (orçamentária) aos demais entes jurídicos de direito público interno, com o intuito de que o possam efetivamente desenvolver os seus respectivos sistemas de atendimento socioeducativo. O sistema nacional de informações sobre o atendimento socioeducativo deverá ser criado pela União, a qual deverá adotar as providências necessárias para o seu regular funcionamento, bem como das entidades e programas que inclusive se destinem à coleta de dados relativos a financiamento e a população atendida. A União deverá estabelecer previsão orçamentária que assegure o repasse de verbas (recursos) públicas aos Estados, Distrito Federal e Municípios, para o financiamento da execução de programas de atendimento, bem como para a implementação, estrutural e funcional, dos serviços inerentes ao Sistema Nacional de Atendimento Socioeducativo (SINASE) (RAMIDOFF, 2012, p. 20).Aos Estados e Municípios são comuns (BRASIL, Sistema Nacional de Atendimento Socioeducativo, p. 32-33):

1) monitorar, supervisionar e avaliar o sistema, a política, os programas e as ações - sob a responsabilidade do ente federativo ou por ele delegado voltadas ao atendimento do adolescente desde o processo de apuração do ato infracional até a aplicação e execução de medida socioeducativa;

2) fornecer, via Poder Executivo, os meios e os instrumentos necessários ao pleno funcionamento do Plantão Interinstitucional nos termos previstos no art. 88, V, do ECA;

3) proporcionar formação inicial e continuada sobre a temática "Criança e Adolescente" para os servidores públicos e as equipes das entidades conveniadas envolvidas no atendimento ao adolescente em conflito com a lei, especialmente às equipes de atendimento e de órgãos responsáveis pela execução de políticas de saúde, Educação, segurança e outras destinadas aos adolescentes;

4) submeter ao competente Conselho dos Direitos da Criança e do Adolescente os programas socioeducativos executados diretamente pela administração pública;

5) implantar e alimentar cotidianamente, por meio de todos os órgãos estaduais e entidades conveniadas, o SIPIA II/ INFOINFRA; 
6) viabilizar o acesso das entidades de defesa dos direitos da criança e do adolescente e de direitos humanos em geral às Unidades de atendimento socioeducativo que estejam sob sua responsabilidade.

De acordo com o artigo $4^{\circ}$ do SINASE, aos Estados competem a formulação, instituição, coordenação e manutenção de seus respectivos sistemas de atendimento socioeducativo, os quais deverão formular suas normativas, levando-se em conta as diretrizes estabelecidas pela União. Os Estados deverão elaborar os seus respectivos planos de atendimento socioeducativo em linha com os ditames orientativos e proposicionais estabelecidos no plano educacional, deliberado e aprovado pelo Conselho Nacional dos Direitos da Criança e do Adolescente - CONANDA (inciso II e $\S 3^{\circ}$ do artigo $3^{\circ}$ do SINASE) (RAMIDOFF, 2012, p.22).

Os planos de atendimento socioeducativos elaborados pelos Estados deverão ser aprovados pelos respectivos Conselhos Estaduais dos Direitos da Criança e do Adolescente (Inciso II, $\S 2^{\circ}$ do artigo $4^{\circ}$ do SINASE). Os Estados são responsáveis pela criação, desenvolvimento e manutenção dos programas de atendimento destinados ao acompanhamento do cumprimento das medidas socioeducativas de (regime) semiliberdade e de internação, bem como pela edição de normas complementares para a organização e funcionamento de seus respectivos sistemas de atendimento, e também dos sistemas de seusmunicípios (RAMIDOFF, 2012, p. 22).

Os Estados deverão estabelecer com os municípios estratégias organizacionais, estruturais, funcionais, em parceria, como forma de colaboração, para a efetivação jurídicolegal e social do atendimento sociopedagógico (socioeducativa) "de meio aberto". Por isso mesmo, os Estados encontram-se legalmente obrigados a prestar assessoria técnica e suplementação financeira aos municípios, para que se assegure a oferta regular de programas de atendimento socioeducativo "de meio aberto" (RAMIDOFF, 2012, p. 23).

Por sua vez, nos moldes do artigo $5^{\circ}$ do SINASE, cabem aos Municípios a formulação, instituição, coordenação e manutenção de seus respectivos sistemas de atendimento socioeducativo, os quais deverão formular suas normativas, levando-se em conta as diretrizes estabelecidas não só pela União, mas, também, pelos correspondentes Conselhos Municipais. Também serão responsáveis pela criação, desenvolvimento e manutenção dos programas de atendimento destinados ao acompanhamento do cumprimento das medidas socioeducativas "de meio aberto", quais sejam de prestação de serviços à comunidade e de 
liberdade assistida.Serão responsáveis ainda, pela edição de normas complementares para a organização e o funcionamento de seus respectivos sistemas de atendimento socioeducativo. Os Municípios deverão estabelecer com os Estados respectivas estratégias organizacionais, estruturais e funcionais, em parceria, como forma de colaboração, para a efetivação jurídicolegal e social do atendimento socio pedagógico (socio educação) "de meio aberto" (RAMIDOFF, 2012, p. 24-25).

Paulo Lúcio Nogueira (1996, p. 87) critica quando defende que muitas das disposições constitucionais e estatutárias, quanto ao dever do Estado para com a Educação, não passam de letras mortas, já que o Estado não tem dado a devida atenção à educação, o que tem contribuído sensivelmente para sua baixa qualidade. O doutrinador realiza, ainda, o seguinte questionamento: "Ora, se o próprio Estado não cumpre o seu dever de priorizar a Educação, o que podemos esperar deste País?”(NOGUEIRA, 1996, p. 87).

O direito define e cristaliza, a seu modo, fins substantivos, como ainda molda e forja instituições encarregadas de persegui-los, influenciando, ainda, as ações e processos destinados a implementar políticas públicas. O direito desempenha uma função discursiva, na medida em que a linguagem dos direitos subjetivos, isto é, "ter direito a algo", é vocalizada para chamar a atenção e assegurar prioridade e certos objetivos, como a proteção dos direitos humanos entre outros. Em outras palavras, o direito agrega ao debate sobre desenvolvimento dimensões que outras disciplinas ou racionalidade das ciências sociais não agregam: ele tematiza, legitima e institucionaliza agendas políticas, dando-lhes um status diferenciado ao positivá-los (COUTINHO, 2013, p. 96).

Vislumbrar o direito como objetivo de iniciativas de desenvolvimento sugere que se reconheça que o arcabouço jurídico tenha a característica de formalizar metas e indicar os "pontos de chegada" de tais políticas. O direito, nesse sentido, pode ser entendido como uma diretriz normativa (prescritiva) que delimita, ainda que de forma geral e sem determinação prévia de meios, o que deve ser perseguido em termos de ação governamental. Ele é, nessa acepção, uma bússola, cujo norte são os objetivos dados politicamente, de acordo com os limites de uma ordem jurídica (COUTINHO, 2013, p. 99). Dessa forma questiona-se: como funcionará o procedimento do acesso à educação dos adolescentes e jovens em cumprimento de medidas socioeducativas? 


\section{A matrícula dos adolescentes e jovens em cumprimento de medidas socioeducativas no Estado do Paraná}

As medidas socioeducativas elencadas no artigo 112 do Estatuto da Criança e do Adolescente objetivam, além de punir, precipuamente educar, bem como ensina Michel Foucault (1987, p. 63). O oferecimento da educação nos estabelecimentos onde são cumpridas as internações é assim de extrema importância, devendo estar comprometida também com valores. Paulo Freire (1967, p. 36) ensina que a vocação ontológica do homem de ser sujeito, auxilia na construção dos sujeitos, de modo que possibilite alternativas, entre elas, a não reincidência na prática de atos infracionais.

Sobressai o caráter pedagógico da medida que, a despeito de não abrir mão do seu caráter retributivo, ou seja, pela imposição de sanção pelo mal praticado, mas foca o seu fundamento básico na educação voltada para a introjeção de valores no adolescente em conflito com a lei, ainda em processo de desenvolvimento, no sentido de fazer com que possa refletir e retornar a conviver, pacificamente, no seio social, tornando-se um cidadão e afastando-se da criminalidade. Há de lhe ser propiciado, no menor espaço de tempo possível, a recuperação do seu status libertatis, indispensável para o seu pleno desenvolvimento físico, intelectual, moral e espiritual, o que se faz através de acompanhamento individualizado levado a efeito por equipe interdisciplinar, com intervenções, inclusive, na família do jovem (BANDEIRA, 2006, p. 82).

No que diz respeito aos adolescentes que praticam ato infracional, o ECA estabelece que estes devam cumprir medidas socioeducativas que lhes oportunizem condições para ressignificar o ato infracional cometido e as suas trajetórias de vida. Nesse sentido, a dimensão pedagógica da socioeducação, traduzida em ação formadora e transformadora dos sujeitos, será um mecanismo de qualificação dos processos de escolarização e profissionalização de adolescentes e jovens. Buscando romper os ciclos de violência e exclusão vivenciados por esses sujeitos, o processo socioeducativo se fundamenta em uma concepção de educação voltada para a autonomia e a vida em liberdade. A articulação e a integração das instâncias públicas governamentais e da sociedade civil são fundamentais para efetivação dos direitos de adolescentes como sujeitos de direitos (BRASIL, Ministério da Educação, 2012, p. 4-5). 
A Lei $n^{\circ} 10.172$, de 9 de janeiro de 2001, que regula o Plano Nacional de Educação PNE, contém em si a $17^{a}$ meta. Esta meta prevê a implantação em todas as unidades prisionais e nos estabelecimentos que atendam adolescentes e jovens em conflito com a lei, de programas de Educação de Jovens e Adultos de nível fundamental e médio, assim como formação profissional, contemplando para esta clientela as metas relativas ao fornecimento de material didático-pedagógico pelo Ministério da Educação - MEC e à oferta de programas de educação à distância. O Plano Nacional de Educação, por meio da meta 26, também define que os poderes públicos deverão sustentar a elaboração e a implementação de programas para garantir a Educação Básica nos sistemas penitenciários (BRASIL, Lei 10.172).

O Parecer CNE/CEB n ${ }^{\circ}$ 11/2000, do Conselho Nacional de Educação, atribui ao EJA (Educação de Jovens e Adultos) a função de restaurar o direito de todos à educação escolar de qualidade. Além disso, o governo torna-se responsável por assegurar as condições necessárias para que o acesso a este direito seja garantido (OHUSHI; VICENTINI, 2012, p. 58). Por ser um serviço público, por ser direito de todos e dever do Estado, é obrigação deste último interferir no campo das desigualdades e, com maior razão no caso brasileiro, no terreno das hierarquias sociais, por meio de políticas públicas. O acesso a este serviço público é uma via de chegada a patamares que possibilitam maior igualdade no espaço social. Tão pesada quanto a iníqua distribuição da riqueza e da renda, é a brutal negação que o sujeito iletrado ou analfabeto pode fazer de si mesmo no convívio social (BRASIL, Ministério da Educação, 2017, p. 5).

Um problema é discutir sobre a adequação da escola para um grupo que não é o alvo principal. Currículos, programa e métodos de ensino foram originalmente concebidos para crianças e adolescentes que percorreriam o caminho da escolaridade regular. Isso implica um pensamento em que jovens e adultos muitas vezes estão em condições inadequadas, ou seja, vivenciam situações que não correspondem ao desenvolvimento de processos de real aprendizagem (OHUSHI; VICENTINI, 2012, p. 59).

O Sistema Nacional de Atendimento Socioeducativo - SINASE, em seu artigo $8^{\circ}$, dispõe que os Planos de Atendimento Socioeducativo deverão obrigatoriamente prever ações articuladas nas áreas de educação, saúde, assistência social, cultura, capacitação para o trabalho e esporte, para os adolescentes atendidos, em conformidade com os princípios elencados no Estatuto da Criança e do Adolescente (BRASIL, Lei 12.594, de 18 de janeiro de 2012). 
$\mathrm{O}$ artigo $6^{\circ}$ da Resolução CNE/CEB n 2/2010 estabelece, ainda, que a "gestão da educação no contexto prisional deverá promover parcerias com diferentes esferas e áreas de governo, bem como com universidades, instituições de educação profissional e organizações da sociedade civil, com vistas à formulação, execução, monitoramento e avaliação de políticas públicas de Educação de Jovens e Adultos em situação de privação de liberdade”. Segundo o parágrafo único do mesmo dispositivo legal, essas parcerias dar-se-ão em perspectiva complementar à política educacional implementada pelos órgãos responsáveis pela Educação da União, dos Estados e do Distrito Federal (BRASIL, Ministério da Educação. Conselho Nacional de Educação).

No âmbito do Estado do Paraná, a Secretaria de Estado da Educação e Superintendência da Educação - SUED/SEED emitiu a Instrução Normativa número 10 de 24 de abril de $2017^{10}$.Tal Instrução Normativa visa atender o previsto na Lei $12.594 / 2012$, que institui o Sistema Nacional de Atendimento Socioeducativo - SINASE, ou seja, a oferta, a qualificação e a consolidação do atendimento escolar de adolescentes e jovens em cumprimento de medidas socioeducativas.

Para tanto, a Secretaria de Estado da Educação - SEED, a Secretaria da Justiça, Trabalho e Direitos Humanos - SEJU, e as instituições da rede pública estadual de ensino, em regime de colaboração e considerando as ações que lhes competem no âmbito de suas atribuições determinadas por lei, devem atuar de modo cooperado visando:

I. Inserir ações voltadas para o atendimento escolar, atendendo aos Planos Municipais e ao Plano Estadual de Educação;

II. Garantir a oferta de todas as etapas da Educação Básica, contemplando diferentes componentes curriculares, nas modalidades mais adequadas às necessidades dos adolescentes e jovens em cumprimento de medidas socioeducativas;

III. Implementar ações para incentivar a permanência dos adolescentes e jovens em cumprimento de medidas socioeducativas e aos egressos nos espaços escolares, de forma a combater a evasão escolar desses estudantes;

${ }^{10}$ PARANÁ. SECRETARIA DE ESTADO DA EDUCAÇÃO SUPERINTENDÊNCIA DE DESENVOLVIMENTO EDUCACIONAL DIRETORIA DE ADMINISTRAÇÃO ESCOLAR COORDENADORIA DE DOCUMENTAÇÃO ESCOLAR. Instrução número 10 de 24 de Abril de 2017. Disponível em: http://www.educacao.pr.gov.br/arquivos/File/instrucoes2017/instrucao102017sued_seed.pdf. Acesso em: 17 maio 2018. 
IV. Priorizar estratégias pedagógicas de enfrentamento a todas as formas de preconceito e discriminação a que os adolescentes e jovens estejam sujeitos.

Quanto à matrícula, a Instrução Normativa SUED/SEED no 10/2017 ${ }^{11}$ prescreve que as instituições de ensino da rede pública deverão assegurar a matrícula dos adolescentes e jovens em cumprimento de medidas socioeducativas, sem a imposição de qualquer forma de embaraço, preconceito ou discriminação, pois se trata de direito fundamental, público e subjetivo, acompanhando as legislações que tratam sobre o tema.

Observa-se que, o legislador se atentou quanto a não incidência da estigmatização dos alunos que cumprem essas modalidades de medidas. Tal ação visa a efetivação do principio da proteção integral da criança e do adolescente, bem como a máxima proteção desses adolescentes e jovens que se encontram em constante desenvolvimento. Objetiva-se aqui conter a prática da violência simbólica ${ }^{12}$. No tópico 2 da Instrução Normativa, passa-se a prescrever como será a oferta da Educação de Jovens e Adultos no cumprimento das medidas socioeducativas de Internação, Internação Provisória, Semiliberdade e em Meio Aberto.

\subsection{Dos adolescentes e jovens que cumprem medida de internação nos Centros de Sócio Educação - CENSE.}

A oferta da Educação Básica aos adolescentes e jovens que cumprem medida socioeducativa em unidades de internação será realizada pela Secretaria de Estado da Educação, através do Programa de Educação nas Unidades Socioeducativas - PROEDUSE, nos Centros de Sócio educação- CENSE, administrados pela Secretaria de Justiça - SEJU.

\footnotetext{
${ }^{11}$ PARANÁ. SECRETARIA DE ESTADO DA EDUCAÇÃO SUPERINTENDÊNCIA DE DESENVOLVIMENTO EDUCACIONAL DIRETORIA DE ADMINISTRAÇÃO ESCOLAR COORDENADORIA DE DOCUMENTAÇÃO ESCOLAR. Instrução número 10 de 24 de Abril de 2017. Disponível em: http://www.educacao.pr.gov.br/arquivos/File/instrucoes2017/instrucao102017sued_seed.pdf. Acesso em: 17/05/2018.

${ }^{12}$ Sobre a "violência simbólica", Jessé Souza explica que é aquele tipo de violência que não "aparece" como violência, que torna possível a naturalização de uma desigualdade social abissal como a brasileira. Na realidade, a "legitimação da desigualdade" no Brasil contemporâneo, que é o que permite a sua reprodução cotidiana indefinidamente, nada tem a ver com esse passado longínquo. Ela é reproduzida cotidianamente por meios "modernos", especificamente "simbólicos", muito diferentes do chicote do senhor de escravos ou do poder pessoal do dono de terra e gente, seja esta gente escrava ou livre, gente negra ou branca. Quando não se fala dessas formas "novas" e "modernas" de se legitimar a dominação cotidiana injusta e se apela a uma suposta e vaga continuidade com o passado distante é porque não se sabe do que se está falando, ainda que não se tenha coragem de admitir. (SOUZA, 2009, p. 15).
} 
Nessas unidades, a oferta educacional será oferecida na modalidade da Educação de Jovens e Adultos - EJA, mediante Ação Pedagógica Descentralizada Especial - APED, vinculada a um Centro Estadual de Educação Básica de Jovens e Adultos - CEEBJA, ou a uma instituição de ensino que oferte esta modalidade.

Segundo a Instrução, as APEDs deverão funcionar em espaços específicos, dotados de infraestrutura adequada, recursos pedagógicos, equipe docente, pedagógica e administrativa capaz de garantir o cumprimento da carga horária mínima estabelecida pela legislação e a qualidade social do processo educacional.A matrícula do adolescente ou jovem, com idade igual ou superior à permitida pela legislação, obrigatoriamente, será realizada na modalidade da EJA na instituição de ensino, sede à qual a APED Especial está vinculada, independente do tempo de cumprimento da medida socioeducativa do interno.

$\mathrm{Na}$ hipótese de matrícula na EJA de adolescente ou jovem com idade inferior à permitida pela legislação vigente, haverá um procedimento específico, em caráter excepcional, segundo versa a Instrução.Após solicitação formal da direção do CENSE, as matrículas deverão ser requisitadas, individualmente, pelo pedagogo do Programa de Educação nas Unidades Socioeducativas -PROEDUSE. Essa solicitação de cadastro da matrícula no Sistema da Educação de Jovens e Adultos - SEJA deverá ser encaminhada à Coordenação de Registro Escolar CRE/DLE/SUED/SEED, constando o ofício de solicitação da inclusão de cadastro e matrícula de aluno na instituição de ensino à qual o CENSE esteja vinculado, o número dos autos, o nome do juiz de direito e da comarca pela qual o adolescente ou jovem foi encaminhado, a certidão de nascimento e/ou cédula de identidade do aluno, o código geral de matrícula (CGM) do aluno, a data para inclusão da matrícula do aluno.

Ao concluir o cadastro de matrícula no SEJA, a CRE/DLE/SUED encaminhará ao solicitante, via correio eletrônico, o comprovante de inserção da(s) matrícula(s) do aluno, que, após essa confirmação para assegurar a matrícula e o direito à continuidade de estudos na EJA, deverá ser registrada na ficha individual do aluno, pela equipe pedagógica do PROEDUSE, e no histórico escolar, pelo secretário da escola sede. E, finalmente arquivar na pasta individual do aluno o ofício de solicitação de inclusão de cadastro e matrícula no SEJA e a confirmação da matrícula emitida pela CRE/DLE/SUED.

Através das previsões legais propostas pelo Estado do Paraná, torna-se juridicamente viável implementar de forma efetiva o acesso à educação de jovens em conflito com a lei e 
que cumprem medidas socioeducativas. A procedimentalização específica dessa inclusão evidencia claramente o interesse do Estado supramencionado em regulamentar a questão em tela, permitindo-se que esses jovens, em razão de sua condição, não sejam mais uma vez excluídos, assegurando-lhes a oportunidade do pleno desenvolvimento, preparação para o mercado de trabalho, exercício da cidadania, além da possibilidade de repensar sua condição humana e envolvimento com atividades que contrariam a legislação brasileira vigente. Dessa forma, torna-se viável pensar na efetiva ressocialização, fato esse que legitima a ressignificação do caráter eminentemente retributivista da medida socioeducativa, permitindose a concretização dos objetivos propostos pelo Estatuto da Criança e do Adolescente.

\subsection{Dos adolescentes e jovens que cumprem medida de internação provisória nos} Centros de Socio educação - CENSE

Nas unidades de internação provisória, a Instrução número 10/2017 ${ }^{13}$ determina a garantia do atendimento educacional, considerando a natureza desta medida, voltado à continuidade do processo de escolarização de adolescentes e jovens já matriculados ou à recondução quando estiverem afastados do processo escolar. Para os adolescentes e jovens que estiverem cumprindo a medida de internação provisória em um Centro de Socioeducação, com matrícula no Sistema Estadual de Registro Escolar - SERE, com frequência registrada e sem distorção idade/ano (quando a diferença entre a idade do aluno e a idade prevista para a série é de dois anos ou mais $)^{14}$, verifica-se:

I. deve-se considerar a frequência até a data do ato infracional e/ou apreensão e, após a autorização da família, visando garantir a frequência escolar durante o período de internação provisória:

a) solicitar à escola de origem o envio de atividades escolares e todo o material de apoio para utilização, nas aulas presenciais, pelos professores do PROEDUSE das disciplinas e/ou das áreas de conhecimento a que pertencem as atividades enviadas;

\footnotetext{
${ }^{13}$ PARANÁ. SECRETARIA DE ESTADO DA EDUCAÇÃO SUPERINTENDÊNCIA DE DESENVOLVIMENTO EDUCACIONAL DIRETORIA DE ADMINISTRAÇÃO ESCOLAR COORDENADORIA DE DOCUMENTAÇÃO ESCOLAR. Instrução número 10 de 24 de Abril de 2017. Disponível em: http://www.educacao.pr.gov.br/arquivos/File/instrucoes2017/instrucao102017sued_seed.pdf. Acesso em: 17 maio 2018.

${ }^{14}$ PARANÁ. SECRETARIA DE ESTADO DA EDUCAÇÃO SUPERINTENDÊNCIA DE DESENVOLVIMENTO EDUCACIONAL DIRETORIA DE ADMINISTRAÇÃO ESCOLAR COORDENADORIA DE DOCUMENTAÇÃO ESCOLAR. Instrução número 10 de 24 de Abril de 2017. Disponível em: http://www.educacao.pr.gov.br/arquivos/File/instrucoes2017/instrucao102017sued_seed.pdf. Acesso em: 17 maio 2018..
} 
b) recomendar a utilização do e-mail, do correio, e/ou dos responsáveis pelos adolescentes e jovens para o envio dessas atividades, de forma a agilizar $\mathrm{o}$ processo;

c) entrar em contato com o NRE ou setor ao qual a escola encontra-se jurisdicionada, quando da ausência de resposta ou negação da escola de origem quanto ao envio das atividades e materiais.

II. a interlocução com a escola de origem deverá ser realizada por intermédio do Pedagogo da APED Especial ou, na ausência dos profissionais do PROEDUSE, pelo Pedagogo da Unidade;

III. em hipótese alguma, durante a interlocução com a APED, deve ser tratado do ato infracional dos adolescentes e jovens, conforme prevê o artigo 232 do ECA (BRASIL, Lei 8069/90);

IV. a equipe do PROEDUSE deverá aproveitar as frequências e as notas de trabalhos e atividades realizadas durante o período de internação provisória e, periodicamente, encaminhar os resultados das avaliações e frequências para registro na escola de origem;

V. após o período de internação provisória, um ofício deverá ser emitido e encaminhado à escola de origem, contendo Parecer Descritivo sobre as atividades desenvolvidas pelo adolescente naquele período.

$\mathrm{Na}$ hipótese dos adolescentes e jovens que estiverem cumprindo a medida de internação provisória, com ou sem matrícula no Sistema Estadual de Registro Escolar SERE, em distorção idade/ano, deve-se matricular na modalidade da EJA os adolescentes ou jovens dentro da faixa etária permitida pela legislação vigente; com idade inferior à permitida pela legislação vigente para matrícula na modalidade da EJA, em caráter excepcional, poderão ser matriculados também nessa modalidade.

O acesso à educação para adolescentes e jovens, que cumprem medida de internação provisória, deve ser assegurado pelo Estado, observando-se os preceitos trazidos pelo Estatuto da Criança e Adolescente, que prevê tratamento jurídico prioritário a esses sujeitos em desenvolvimento. Em razão disso, constitui dever dos Estados da federação regulamentar no plano infraconstitucional como se dará o acesso à educação para esses jovens. A privação temporária da liberdade, em razão da internação, não poderá acarretar na negativa de acesso à formação educacional continuada. Em razão disso, ao Estado caberá o dever de regulamentar, planejar e executar politicas públicas que assegurem com efetividade o direito desses jovens continuarem a ter acesso à educação básica, como mecanismo essencial a sua ressocialização, preparação para o mercado de trabalho, exercício da cidadania, além da possibilidade de compreender sua condição humana de envolvimento com atividades ilícitas previstas no Estatuto da Criança e do Adolescente. O Estado do Paraná é pioneiro na regulamentação legal do acesso à educação aos jovens que cumprem medidas socioeducativas, o que evidencia seu 
real interesse em assegurar o cumprimento integral das diretrizes normativas preconizadas pela legislação federal e o texto constitucional.

\subsection{Dos adolescentes e jovens que cumprem medida de semiliberdade}

Ao adolescente ou jovem que estiver cumprindo a medida socioeducativa de semiliberdade, a Instrução SUED/SEED n ${ }^{\circ}$ 10/2017 ${ }^{15}$ prevê, independente da idade, o dever de assegurar a possibilidade de continuidade dos estudos por meio do ingresso na escola ou centros de educação profissional existentes na comunidade, a qualquer momento do ano letivo. Ou seja, o referido diploma legal possibilita ao jovem infrator o direito de exercer com efetividade o direito fundamental à educação, como meio de alcançar o pleno desenvolvimento da pessoa humana, preparação para o mercado de trabalho, além da possibilidade de exercício da cidadania mediante a compreensão da sua própria condição enquanto transgressor das normas jurídicas vigentes.

Para os adolescentes e jovens sem matrícula, oriundos ou não das unidades de internação, deve-se assegurar a possibilidade do ingresso na escola a qualquer momento do ano letivo, desde que se submeta a processo de classificação, aproveitamento e adaptação previstos no regimento escolar, sendo que o controle de frequência se fará a partir da data efetiva da matrícula. A flexibilidade normativa proposta justifica-se em razão da importância do processo continuo de formação educacional na vida da pessoa humana, especialmente do adolescente e jovem, considerados pessoas em desenvolvimento, nos termos dispostos no Estatuto da Criança e do Adolescente.

No caso dos adolescentes e jovens que não são oriundos das unidades de internação, sem matrícula e com idade inferior à permitida pela legislação vigente para ingresso na EJA, a Instrução determina a garantia de vagas e matrículas no ensino regular. Já para os adolescentes ou jovens oriundos das unidades de internação provisória ou internação com matrícula ativa na Educação de Jovens e Adultos - EJA, preferencialmente e independente da idade, deve-se manter a matricula nesta modalidade na instituição de ensino da rede mais próxima da residência do aluno ou, na ausência desta, realizar-se-ão as adaptações e

${ }^{15}$ PARANÁ. SECRETARIA DE ESTADO DA EDUCAÇÃO SUPERINTENDÊNCIA DE DESENVOLVIMENTO EDUCACIONAL DIRETORIA DE ADMINISTRAÇÃO ESCOLAR COORDENADORIA DE DOCUMENTAÇÃO ESCOLAR. Instrução número 10 de 24 de Abril de 2017. Disponível em: http://www.educacao.pr.gov.br/arquivos/File/instrucoes2017/instrucao102017sued_seed.pdf. Acesso em: 17 maio 2018. 
aproveitamento de estudos necessários ao ajustamento do aluno ao novo currículo de acordo com as medidas previstas no regimento escolar da instituição.

A partir da análise das disposições legais expostas, verifica-se que o Estado do Paraná é pioneiro na regulamentação detalhada e pontual do direito de acesso à educação para os jovens e adolescentes aos quais foram aplicadas medidas socioeducativas. Trata-se proposta que viabiliza a efetivação do direito à educação, essencial ao pleno desenvolvimento da pessoa humana, e cujo acesso não pode ser restrito em razão da aplicabilidade da norma que regulamenta as medidas socioeducativas. Mesmo diante de tal situação, cabe ao Estado planejar e executar políticas públicas voltadas ao acesso igualitário à formação educacional continuada, como mecanismo de inclusão e oportunidade de exercício dos demais direitos fundamentais previstos no plano constituinte.

\subsection{Dos adolescentes e jovens que cumprem medida em meio aberto}

Segundo a Instrução SUED/SEED n ${ }^{\circ}$ 10/2017¹6 , os Núcleos Regionais de Educação, em consonância com as demais instituições (famílias, conselhos tutelares, Ministério Público, poder judiciário), aliado ao plano de atendimento com ação especializada de caráter pedagógico, psicossocial e jurídico-social executado pelas equipes intersetoriais que atuam nos CREAS/FAS, deverão assegurar a possibilidade de continuidade dos estudos ou do ingresso na escola a qualquer momento do ano letivo aos adolescentes e jovens em cumprimento de medida de liberdade assistida e prestação de serviços à comunidade.

Prioritariamente, aos adolescentes e jovens com idade inferior à permitida pela legislação para ingresso na EJA, devem-se garantir vagas e matrículas no ensino regular, e em caráter excepcional, os adolescentes e jovens com idade inferior poderão ser matriculados na modalidade EJA.Os adolescentes e jovens em cumprimento de medida socioeducativa em meio aberto, quando matriculados, poderão ser submetidos a uma avaliação pedagógica destinada a detectar possíveis deficiências de aprendizagem e/ou perda dos conteúdos ministrados, com o subsequente planejamento de atividades destinadas a assegurar o bom

${ }^{16}$ PARANÁ. SECRETARIA DE ESTADO DA EDUCAÇÃO SUPERINTENDÊNCIA DE DESENVOLVIMENTO EDUCACIONAL DIRETORIA DE ADMINISTRAÇÃO ESCOLAR COORDENADORIA DE DOCUMENTAÇÃO ESCOLAR. Instrução número 10 de 24 de Abril de 2017. Disponível em: http://www.educacao.pr.gov.br/arquivos/File/instrucoes2017/instrucao102017sued_seed.pdf. Acesso em: 17 maio 2018. 
aproveitamento escolar. Os Núcleos Regionais de Educação divulgarão os cronogramas anuais de exames de larga escala para certificação de competências, nacionais e locais, às equipes intersetoriais responsáveis pela execução de medidas socioeducativas em meio aberto, priorizando a participação de adolescentes e jovens em atendimento, que estejam em distorção idade/ano e/ou matriculados na Educação de Jovens e Adultos.

Os adolescentes e jovens em cumprimento dessa modalidade de medida socioeducativa, matriculados no Sistema Estadual de Ensino, terão prioridade em vagas na Educação Integral, em tempo integral, nos municípios onde houver essa oferta e atendimento educacional especializado, quando necessário.

Segundo a Instrução ${ }^{17}$, quando o adolescente ou jovem, matriculado nos Sistemas SERE ou SEJA, se tornar infrequente, a escola deverá informar a equipe intersetorial responsável pela execução de medidas socioeducativas e acionar diretamente a Rede de Proteção dos Direitos da Criança e do Adolescente, da qual também é integrante, para que outras ações destinadas a promover o retorno do estudante à escola sejam desencadeadas, a partir da análise das peculiaridades de cada caso.

Dessa forma, ao realizar a análise da a Instrução SUED/SEED n ${ }^{\circ}$ 10/2017 ${ }^{18}$, emitida pela Secretaria de Estado de Educação do Paraná, conclui-se que, após transcorrido cinco anos da promulgação do SINASE, o direito à educação no âmbito do Estado do Paraná está sendo efetivado ao ser ofertada aos adolescentes e jovens em cumprimento de medidas socioeducativas. A Instrução trata do procedimento da matricula em medidas em meio aberto, semiaberto e em regime de internação, trazendo o passa a passo de como deve-se ocorrer na aplicação de cada medida.

Tais propostas visam assegurar facilidade no acesso à formação educacional continuada, além da previsão de inúmeros mecanismos de manutenção e permanência do aluno na escola. Ao estabelecer o direito de o aluno ser matriculado em escola próxima a sua

\footnotetext{
${ }^{17}$ PARANÁ. SECRETARIA DE ESTADO DA EDUCAÇÃO SUPERINTENDÊNCIA DE DESENVOLVIMENTO EDUCACIONAL DIRETORIA DE ADMINISTRAÇÃO ESCOLAR COORDENADORIA DE DOCUMENTAÇÃO ESCOLAR. Instrução número 10 de 24 de Abril de 2017. Disponível em: http://www.educacao.pr.gov.br/arquivos/File/instrucoes2017/instrucao102017sued_seed.pdf. Acesso em: 17 maio 2018.

${ }^{18}$ PARANÁ. SECRETARIA DE ESTADO DA EDUCAÇÃO SUPERINTENDÊNCIA DE DESENVOLVIMENTO EDUCACIONAL DIRETORIA DE ADMINISTRAÇÃO ESCOLAR COORDENADORIA DE DOCUMENTAÇÃO ESCOLAR. Instrução número 10 de 24 de Abril de 2017. Disponível em: http://www.educacao.pr.gov.br/arquivos/File/instrucoes2017/instrucao102017sued_seed.pdf. Acesso em: 17 maio 2018.
} 
residência; ao permitir que a matrícula se efetive a qualquer momento do ano letivo, o Estado do Paraná demonstra com clareza e objetividade sua verdadeira intenção de assegurar o amplo acesso e permanência do adolescente infrator na escola, para que a aplicabilidade da medida socioeducativa não venha a constituir óbice ao exercício do referido direito, expressamente previsto no plano constituinte, instituinte e infraconstitucional.

\section{Conclusão}

A educação tem sua importância reconhecida jurídico-constitucionalmente no Brasil, sendo esse reconhecimento reflexo muito forte na legislação pátria vigente. A educação está diretamente ligada ao pleno desenvolvimento do indivíduo, contribuindo para a formação de sua personalidade, bem como a aptidão para o convívio social, preparo para o exercício da cidadania e sua qualificação para o trabalho de trabalho. Nesse sentido, a Instrução Normativa 10/2017, emitida pela Secretaria de Educação do Estado do Paraná, constitui um meio de assegurar a efetividade do direito à educação dos adolescentes em conflito com a lei e aos quais foram aplicadas judicialmente medidas socioeducativas. Por meio do referido diploma legal vigente, assegura-se maior facilidade de acesso e permanência na escola, garante-se o direito desses adolescentes e jovens não serem privados ou limitados no acesso à educação no período de cumprimento das medidas socioeducativas. Fica assim evidente o interesse do Estado do Paraná em planejar e executar política pública educacional para esse público específico, assegurando-se o acesso igual e facilitado de se matricular e permanecer matriculado na escola.

O direito à educação é garantido no ordenamento jurídico pátrio através de uma sistematização, por meio de princípios, atos normativos, regulamentos, dentre outros, objetivando a efetivação desse direito, além da relação entre a União, Estados e Municípios através de suplementação e complementariedade. A esse ramo do direito que regulamenta e normatiza a educação, dá-se o nome de direitos educacionais.Sob o viés educacional, é através do estudo dos direitos educacionais, mais especificamente do Sistema Nacional de Atendimento Socioeducativo - SINASE que se analisa a garantia do direito ao acesso à educação através do procedimento da matrícula do adolescente e jovem que cumpre medidas socioeducativas. 
Mesmo diante do problema da efetivação e a vocalização de direitos que a legislação brasileira tem se defrontado, no âmbito do Estado do Paraná, a Secretaria de Estado da Educação e Superintendência da Educação - SUED/SEED buscou efetivar e padronizar esse acesso através da elaboração da Instrução Normativa no 10/2017, que regulamentou o procedimento das matriculas dos adolescentes e jovens que cumprem medidas socioeducativas em regime de internação, semiliberdade e em meio aberto. Atualmente, a referida Instrução Normativa permite a realização da matrícula dos adolescentes e jovens que estão em conflito com a lei e que tenham efetivado o direito ao acesso à educação básica no interior dos Centros de socio educação - CENSE, no regime de internação, e à rede regular de ensino disponível na comunidade àqueles que cumprem medidas socioeducativas em regime de semiliberdade e em meio aberto.

Trata-se de uma orientação procedimental, apresentando o "passa a passo" de como a matricula deve ocorrer nas diferentes modalidades de medidas, bem como atribuindo as competências, responsabilidades e as atribuições de cada órgão quanto à garantia do direito ao acesso à educação.O cerceamento do direito à educação, mesmo em situações de restrição de liberdade, constitui evidente violação ao direito da personalidade, do princípio da proteção integral da criança e do adolescente e do direito à educação.

Nesse sentido, o Estado do Paraná demonstra a importância de garantir o acesso amplo, efetivo e igualitário do direito à educação aos adolescentes e jovens que cumprem medidas socioeducativas, privilegiando o tratamento de cada caso concreto, levando-se em consideração as peculiaridades vivenciadas por cada jovem em conflito com a lei. Trata-se de disposição legal voltada à garantir a plenitude do acesso e permanência na escola, prevenindo que a medida socioeducativa aplicada seja vista como um instrumento de restrição do exercício do direito à educação, essencial ao pleno desenvolvimento da pessoa humana.

\section{Referências}

BANDEIRA, Marcos Antônio Santos. Atos Infracionais e Medidas Socioeducativas:uma leitura dogmática, crítica e constitucional. Ilhéus: Editus, 2006.

BASTOS, Aurélio Wander. O Ensino Jurídico no Brasil. 2 ed. Rio de Janeiro: Editora Lumen Juris, 2000.

BITTAR, Carlos Alberto. Os Direitos da Personalidade. 3 ed. Rio de Janeiro: Forense, 1999. 
BRASIL. Lei no 10.172, de 9 de janeiro de 2001. Plano Nacional de Educação - PNE. Disponível em: http://www.planalto.gov.br/ccivil_03/leis/leis_2001/110172.htm. Acesso em: 12 maio 2018.

BRASIL. Ministério da Educação. Conselho Nacional de Educação.Diretrizes Nacionais para $o$ atendimento escolar de adolescentes e jovens em cumprimento de medidas socioeducativas. Disponível em: http://www.sinprors.org.br/arquivos/legislacao/Resolu\%C3\%A7\%C3\%A3o_Ceb_n2_2010.pdf. Acesso em 20/ jun. 2018.

BRASIL. Lei $n^{\circ}$ 8.069, de 13 de julho de 1990. Estatuto da Criança e do Adolescente - ECA. Disponível em: http://www.planalto.gov.br/ccivil_03/leis/18069.htm. Acesso em: 17 maio 2018.

BRASIL. Constituição da República Federativa do Brasil de 1988. Disponível em: http://www.planalto.gov.br/ccivil_03/constituicao/constituicaocompilado.htm. Acesso em: 30 maio 2018..

BRASIL. Lei 9.394 de 20 de dezembro de 1996. Lei de Diretrizes e Bases da Educação Nacional.Disponível em: http://www.planalto.gov.br/ccivil_03/leis/L9394.htm. Acesso: em 08 nov. 2017.

BRASIL. Ministério da Educação. Parecer $C N E / C E B n^{\circ} 8$ de 7 de Outubro de 2015.Disponível em: http://portal.mec.gov.br/pnaes/323-secretarias-112877938/orgaosvinculados-82187207/12992-diretrizes-para-a-educacao-basica. Acesso em 05 dez. 2017.

BRASIL. Sistema Nacional de Atendimento Socioeducativo - SINASE/Secretaria Especial dos Direitos Humanos - Brasília-DF: CONANDA, 2006. Disponível em:

http://www.conselhodacrianca.al.gov.br/sala-de-imprensa/publicacoes/sinase.pdf. Acesso em: 28 dez. 2017.

BRASIL. Conselho Nacional dos Direitos das Crianças e dos Adolescentes - CONANDA. Resolução n. $^{\circ} 119$, de 11 de Dezembro de 2006.Disponível em: http://www.crianca.mppr.mp.br/arquivos/File/download/resolucao_119_conanda_sinase.pdf. Acesso em 05 dez. 2017.

BRASIL. Ministério da Educação. Parecer CNE/CEB $n^{\circ} 11$ de 10 de Maio de 2000.Disponível em: http://portal.mec.gov.br/secad/arquivos/pdf/eja/legislacao/parecer_11_2000.pdf. Acesso em 06 dez. 2017.

BULOS, Uadi Lammêgo. Curso de direito constitucional. 8. ed. rev. atual. de acordo com a Emenda Constitucional 76/2013. São Paulo: Saraiva, 2014.

CANTALI, Fernanda Borghetti. Direitos da personalidade:disponibilidade relativa, autonomia privada e dignidade humana. Porto Alegre: Livraria do Advogado, 2009. 
COUTINHO, Diogo R. Direito, desigualdade e desenvolvimento. [recurso eletrônico]. São Paulo: Saraiva. 2013.

FOUCAULT, Michel. Vigiar e punir:nascimento da prisão. Tradução: Raquel Ramalhete. 20. ed. Petrópolis: Vozes, 1987.

FREIRE, Paulo. Educação como prática de liberdade. Rio de Janeiro: Paz e Terra, 1967.

GOMES, Magno Federeci. Delimitação de atribuições educacionais:sistemas de ensino e competência constitucional in Revista bras. Est. pedag., Brasília, v. 92, n. 230, p. 166-186, jan./abr. 2011.

JOAQUIM, Nelson. Direito Educacional Brasileiro:História, teoria e prática. 1 ed. Rio de Janeiro: Livre Expressão, 2009.

KOSTIUK, G. S. [et al.]. Alguns aspectos da relação recíproca entre Educação e desenvolvimento da personalidade in Psicologia e pedagogia: Bases psicológicas da aprendizagem e do desenvolvimento. Tradução: Rubens Eduardo Frias. São Paulo: Centauro, 2005.

LAGO, Andrea Carla de Moraes Pereira. Direito Educacional:prevenção da violência e solução de conflitos pela mediação escolar. 1 ed. Maringá: IDDM, 2013.

MOTTA, Elias de Oliveira. Direito Educacional e Educação no século XXI: com comentários à nova Lei de Diretrizes e Bases da Educação Nacional. Brasília: Unesco, 1997.

MOTTA, Ivan Dias da; FREITAS, Pedro Ferreira de. O direito à Educação como direito da personalidade e o mínimo existencialin Revista Jurídica do Cesumar. v. 3. n. 6, dez 2015.

MUNIZ, Regina Maria Fonseca. O Direito à Educação. rev. Rio de Janeiro: Renovar, 2002.

NOGUEIRA, Paulo Lúcio. Estatuto da Criança e do adolescente comentado:Lei 8.069/90, de 13 de julho de 1990.São Paulo: Saraiva, 1996.

NUCCI, Guilherme de Souza. Estatuto da Criança e do Adolescente comentado: em busca da Constituição Federal das crianças e dos adolescentes. 2. ed. rev.atual. e ampl. Rio de Janeiro: Forense, 2015.

OHUSCHI, Márcia Cristina Greco; VICENTINI, Dalva Linda. Teoria e prática na Educação de jovens e adultos. Maringá-PR: Centro Universitário de Maringá - UNICESUMAR, 2012.

PARANÁ. Secretaria de Estado da Educação Superintendência de Desenvolvimento Educacional Diretoria de Administração Escolar Coordenadoria de Documentação Escolar. Instrução número 10 de 24 de Abril de 2017. Disponível em:

http://www.educacao.pr.gov.br/arquivos/File/instrucoes2017/instrucao102017sued_seed.pdf. Acesso em: 17 maio 2018. 
RAMIDOFF, Mário Luiz. Sinase - Sistema nacional de atendimento socioeducativo.Comentários à Lei 12.594, de 18 de janeiro de 2012. São Paulo: Saraiva, 2012.

RANIERI, Nina Beatriz. Educação superior, direito e estado:na lei de diretrizes e bases (Lei n. 9.394/96). São Paulo: Editora Universidade de São Paulo, FAPESP, 2000.

REGO, Tereza Cristina. Vygotsky:uma perspectiva histórica-cultural da Educação. Petrópolis, RJ: Vozes, 1995.

ROSSATO, Luciano Alves; LÉPORE, Paulo Eduardo; CUNHA, Rogério Sanches. Estatuto da criança e do adolescente comentado:Lei 8.069/1990: artigo por artigo. 4. ed. rev. atual. e ampl. São Paulo: Editora Revistas dos Tribunais, 2012.

ROMÃO, José Eustáquio. Sistemas municipais de Educação:a Lei de Diretrizes e Bases (LDB) e a Educação no município. São Paulo: Editora e Livraria Instituto Paulo Freire, 2010.

SAVIANI, Dermeval. Educação brasileira:estrutura e sistema. 11. ed. rev. Campinas-SP: Autores Associados, 2012.

SILVA, José Afonso da. Curso de Direito Constitucional Positivo. 16 ed. rev. atual. São Paulo: Malheiros, 1999.

SILVA, Virgílio Afonso da. A Constituição do direito:os direitos fundamentais nas relações entre particulares. 1. ed. São Paulo: Malheiros. 2011.

SOUZA, Jessé. Ralé Brasileira:Quem é e como vive.Belo Horizonte: Editora UFMG, 2009.

SOUSA, Eliane Ferreira de. Direito à Educação:requisito para o desenvolvimento do país. São Paulo: Saraiva, 2010.

SZANIAWSKI, Elimar. Direitos de Personalidade e Sua Tutela.2 ed. São Paulo: Revista dos Tribunais, 2005.

VERONESE, Josiane RosePetry; LIMA, Fernanda da Silva. O Sistema Nacional de Atendimento Socioeducativo (Sinase):breves consideraçõesin Revista Brasileira Adolescência e Conflitualidade, 1(1): 29-46, 2009.

VYGOTSKY, Lev Semenovich [et al.]. Aprendizagem e desenvolvimento intelectual na idade escolar in Psicologia e pedagogia: Bases psicológicas da aprendizagem e do desenvolvimento. Tradução: Rubens Eduardo Frias. São Paulo: Centauro, 2005.

VYGOTSKY, Lev Semenovich. A formação social da mente:o desenvolvimento dos processos psicológicos superiores. Tradução: José Cipolla Neto, Luís Silveira Menna Barreto, Solange Castro Afeche. 6. ed. São Paulo: Martins Fontes, 1998. 